\title{
A Coagulation Pathway on Bovine Aortic Segments Leading to Generation of Factor $\mathbf{X}_{\mathrm{a}}$ and Thrombin
}

\author{
David M. Stern, Peter P. Nawroth, Walter Kisiel, \\ Dean Handley, Michael Drillings, and Jola Bartos \\ Department of Medicine, Columbia University College of \\ Physicians and Surgeons, New York 10032; Department of \\ Biochemistry, University of Washington, Seattle, Washington \\ 98195; and Sandoz, Inc., East Hanover, New Jersey 07936
}

bstract. Previous studies have demonstrated the binding of Factors IX and IX $\mathrm{X}_{\mathrm{a}}$ to cultured bovine aortic endothelial cells. The present study examines the interaction of Factors IX, IX $\mathbf{x}_{\mathrm{a}}$, and $\mathrm{X}_{\mathrm{a}}$ with the luminal surface of calf aortas, shown by microscopic examination to have a continuous layer of endothelium. Radioimmunoassay of Factor IX showed that $74 \mathrm{fmol} / 10^{6}$ cells of Factor IX could be eluted from freshly prepared aortic segments. Binding of ${ }^{3} \mathrm{H}$-Factors IX and IX aortic segments was saturable, and comparable to binding in previous studies using cultured endothelial cells. Preincubation of aortic segments with ${ }^{3} \mathrm{H}$-Factor $\mathrm{IX}_{\mathrm{a}}$ and von Willebrand factor (VWF)/Factor VIII, followed by washing and addition of Factor $\mathrm{X}$, resulted in formation of Factor $\mathrm{X}_{\mathrm{a}}$. The addition of prothrombin to these activation mixtures resulted in formation of thrombin. Exogenous phospholipid and Factor $\mathrm{V}$ were not required for Factor $\mathrm{X}$ and prothrombin activation on the intact native endothelium.

Incubation of ${ }^{125} \mathrm{I}$-Factor $\mathrm{X}_{\mathrm{a}}$ with the vessel segments resulted in most of the tracer being complexed with antithrombin III originally present on the aortic segment (3.8 pmol antithrombin III $/ 10^{6}$ cells). The Factor $\mathrm{X}_{\mathrm{a}}$-antithrombin III complex was observed by sodium dodecyl sulfate-polyacrylamide gel electrophoresis exclusively in the supernatants. ${ }^{125} \mathrm{I}$-Factor $\mathrm{X}_{\mathrm{a}}$ not complexed with antithrombin III bound specifically to the vessel

This work has been submitted for the Annual Meeting of the American Association of Pathologists, 1-6 April 1984, St. Louis, MO.

Dr. Stern is a recipient of a Clinician-Scientist Award from the American Heart Association.

Received for publication 6 February 1984 and in revised form 12 July 1984.

J. Clin. Invest.

(C) The American Society for Clinical Investigation, Inc.

$0021-9738 / 84 / 12 / 1910 / 12 \$ 1.00$

Volume 74, December 1984, 1910-1921 segment. The time course of binding was biphasic, consisting of an initial more rapid reversible phase followed by a slower irreversible phase. The latter phase correlated with the formation of a covalent complex $\left(M_{r}, 76,000\right)$ between ${ }^{125} I$-Factor $X_{a}$ and a vessel-localized protein presumably distinct from antithrombin III. The activation of prothrombin by vessel-bound Factor $\mathbf{X}_{\mathbf{a}}$ was inhibited by anti-bovine Factor V IgG, suggesting that there is interaction of Factor $X_{a}$ with a Factor $\mathrm{V}$-like molecule provided by the endothelial cell surface. Addition of antibody to antithrombin III prevented formation of Factor $\mathrm{X}_{\mathrm{a}}$-antithrombin III and thrombinantithrombin III complexes in the supernatant and increased apparent thrombin activity 30-50-fold. These studies demonstrate that freshly obtained vessels with a continuous layer of native endothelium can support activation of Factor $X$ and prothrombin: vessel-bound Factor $\mathrm{IX}_{\mathrm{a}}$ can activate Factor $\mathrm{X}$ in the presence of VWF/Factor VIII. Factor $X_{a}$ can also bind to the vessel and participate in the activation of prothrombin. The apparent efficiency of prothrombin activation, however, is dampened by the presence of functional antithrombin III on the vessel wall.

\section{Introduction}

Localized blood coagulation is important in both hemostasis and thrombosis. Endothelial cells inhibit thrombosis by synthesis of prostacyclin (1), plasminogen activator (2), and thrombomodulin (3), and by the presence of antithrombin III cofactor activity (4); they have the potential to support coagulation by generation of tissue factor (5), von Willebrand factor (VWF) ${ }^{1}(6)$, and thromboxane (7). Recently, there has

1. Abbreviations used in this paper: buffer $\mathrm{A}, 10 \mathrm{mM}$ Hepes (pH 7.45) containing $137 \mathrm{mM} \mathrm{NaCl}, 4 \mathrm{mM} \mathrm{KCl}, 11 \mathrm{mM}$ glucose, $2.5 \mathrm{mM}$ $\mathrm{CaCl}_{2}$, and $5 \mathrm{mg} / \mathrm{ml}$ bovine serum albumin, fatty acid free; buffer $\mathrm{B}$, buffer $A$ with $10 \mathrm{mM}$ EDTA in place of $\mathrm{CaCl}_{2}$; buffer $\mathrm{C}, 50 \mathrm{mM}$ Tris- 
been increased interest in clot-promoting activities of endothelium, and we and other groups reported that Factors IX, IX $X$, and $X_{a}$ bind to bovine aortic endothelial cells in culture $(8-13)$. Cell-bound Factors IX and IX $\mathrm{X}_{\mathrm{a}}$ retain their coagulant properties: cell-bound Factor IX can be activated by either the intrinsic or extrinsic pathways, and cell-bound Factor $\mathrm{IX}_{\mathrm{a}}$ can participate in Factor $X$ activation (10). Factor $X_{a}$ incubated with nonconfluent cultured endothelial cells can activate prothrombin (14). Conclusions from these studies rely on the assumption that cultured endothelial cells are a model for native endothelium. In the present study we have examined the interaction of Factors IX, IX $\mathrm{I}_{\mathrm{a}}$, and $\mathrm{X}_{\mathrm{a}}$ with intact native bovine aortic endothelium to determine whether these factors could bind specifically to the surface and whether the bound factors could lead to generation of thrombin. The results of the present study indicate that the native endothelium can support the activation of Factor $\mathrm{X}$ and prothrombin. These reactions are influenced by the presence of antithrombin III on the vessel wall.

\section{Methods}

Coagulation factors. Bovine coagulation factors were used throughout these studies. Bovine Factor IX was purified to homogeneity (260 $\mathrm{U} / \mathrm{mg}$ ) by the method of Fujikawa et al. (5). Factor IX was tritiated $\left(3.26 \times 10^{6} \mathrm{cpm} / \mu \mathrm{g}\right)$ as described previously (9) and its coagulant activity was unaffected by the radiolabeling procedure. Tritiated Factor IX was activated by incubation with Factor $\mathrm{XI}_{\mathbf{a}}$ bound to $\mathrm{CNBr}$ Sepharose (Pharmacia Fine Chemicals, Piscataway, NJ) at $37^{\circ} \mathrm{C}$ in Tris-buffered saline $(0.05 \mathrm{M}$, Tris- $\mathrm{HCl}, \mathrm{pH} 7.5,0.1 \mathrm{M} \mathrm{NaCl})$ containing $5 \mathrm{mM} \mathrm{CaCl}_{2}$ as described previously (9). A radioimmunoassay was developed to quantify the amount of Factor IX eluted from vessel segments. For the radioimmunoassay Factor IX was iodinated to achieve a higher specific radioactivity. Iodination was carried out by the lactoperoxidase method (16) using the Enzymobead Reagent (BioRad Laboratories, Sacramento, CA). After the radioiodination procedure, Factor IX retained full coagulation activity, migrated as a single chain on reduced sodium dodecyl sulfate polyacrylamide gel electrophoresis (SDS-PAGE) with a molecular weight of 55,000, and had a specific radioactivity of $0.8-1.2 \times 10^{4} \mathrm{cpm} / \mathrm{ng}$.

Bovine Factor $X_{1}$, purified to homogeneity by the method of Fujikawa et al. (17), was activated by incubation with the Factor $X$ activator from Russell's viper venom (18) previously coupled to CNBrSepharose in Tris-buffered saline containing $5 \mathrm{mM} \mathrm{CaCl}_{2}$ (19). Activation reached a plateau by $10 \mathrm{~min}$ as judged by coagulation assay (100 $\mathrm{U} / \mathrm{mg}$ ) performed by the method of Bajaj and Mann (20), and SDSPAGE, which showed complete cleavage of the zymogen. Active siteblocked Factor $\mathbf{X}_{\mathbf{z}}$ (Factor $\mathbf{X}_{\mathbf{z i}}$ ) was prepared by reacting Factor $\mathbf{X}_{\mathbf{a}}$ in $5 \mathrm{mM}$ 2-( $N$-morpholino)-ethanesulfonic acid, $\mathrm{pH} 6.0,0.1 \mathrm{M} \mathrm{NaCl}$ for 60 min with a 10-fold molar excess of (p-amidinophenyl)-methanesulfonyl-fluoride (Calbiochem-Behring Corp., San Diego, CA) as described

$\mathrm{HCl}(\mathrm{pH} 7.8), 175 \mathrm{mM} \mathrm{NaCl}, 10 \mathrm{mM}$, EDTA, $0.5 \mathrm{mg} / \mathrm{ml}$ ovalbumin; Factor $X_{\mathrm{ai}}$, active site-blocked Factor $\mathrm{X}_{\mathrm{a}} ; \mathrm{FAF}$, fatty acid free; PAGE, polyacrylamide gel electrophoresis; S-2222, Bz-Ile-Glu-Gly-Arg-p-nitroanilide; S-2238, H-D-Phe-Pip-Arg-p-nitroanilide; VWF, von Willebrand factor. by Laura et al. (21). Unreacted inhibitor was removed by dialysis at $4^{\circ} \mathrm{C}$ against Tris-buffered saline. Factor $\mathrm{X}_{\mathrm{ai}}$ had no detectable activity in a clotting assay and did not hydrolyze Bz-Ile-Glu-Gly-Arg-p-nitroanilide (S2222) (Helena Laboratories, Beaumont, TX) in the Factor $\mathbf{X}_{\mathrm{a}}$ chromogenic substrate assay (see below). Factors $X_{\mathbf{a}}$ and $\mathbf{X}_{\mathbf{a i}}$ were iodinated by the lactoperoxidase method as described for Factor IX. After the iodination procedure Factor $\mathbf{X}_{\mathbf{a}}$ retained coagulant activity and had a specific radioactivity of $0.6-1.3 \times 10^{4} \mathrm{cpm} / \mathrm{ng}$. ${ }^{125} \mathrm{I}$-Factor $\mathrm{IX}_{\mathrm{ai}}$ had a specific radioactivity of $0.7-1.3 \times 10^{4} \mathrm{cpm} / \mathrm{ng}$. The radioactivity profile of reduced ${ }^{125}$ I-Factor $\mathrm{X}_{\mathrm{a}}$ (Fig. $5 \mathrm{~A}$ ) showed that the heavy chain, light chain, and activation peptide had been labeled. Although immediately after activation Factor $\mathbf{X}_{\mathbf{a}}$ was predominantly in the $\alpha$-form, by the time it was used in these studies Factor $X_{\mathbf{a}}$ was principally in the $\beta$-form (19). ${ }^{125} I$-Factors $X_{\mathbf{a}}$ and $X_{\mathbf{a}}$ appeared identical by SDS-PAGE. SDS-PAGE of ${ }^{125}$ I-Factor $X_{a}$ after gel filtration on Sephadex G75 in Tris-buffered saline demonstrated noncovalent association of the activation peptide with Factor $\mathrm{X}_{\mathbf{a}}$ as previously reported by Furie et al. (22).

Bovine factor VWF/Factor VIII was prepared by the method of Newman et al. (23). It was then chromatographed on an antifibrinogen and antifibronectin affinity column. The final material was homogenous on reduced 5\% SDS-PAGE, showing one band with a molecular weight about 200,000 corresponding to the VWF. The VWF/Factor VIII preparations used in this work had a protein concentration of 1.1 $\mathrm{mg} / \mathrm{ml}$ and a Factor VIII coagulant activity of $70 \mathrm{U} / \mathrm{ml}$. Factor VIII coagulant activity in this preparation was stable over 6 mo of storage at $-80^{\circ} \mathrm{C}$, and no other coagulant activities (including Factors VII, IX, X, XI, and XII) were detected by clotting assay. VWF/Factor VIII $(10 \mathrm{U} / \mathrm{ml})$ was activated by incubation with bovine $\alpha$-thrombin $(0.01$ $\mathrm{U} / \mathrm{ml})$ in Tris-buffered saline for $3 \mathrm{~min}$ and was used immediately $(10$, 24). Bovine $\alpha$-thrombin (2.5 NIH U/ $/ \mu \mathrm{g})$, prothrombin ( $13 \mathrm{U} / \mathrm{mg}$ ), and Factor VII $(7,100 \mathrm{U} / \mathrm{mg})$ were purified to homogeneity as described previously (25-27). Thrombin was iodinated by the lactoperoxidase technique (see above); the radiolabeled protein had a specific radioactivity of 4-8 $\times 10^{3} \mathrm{cpm} / \mathrm{ng}$ and the coagulant activity was unaffected by radiolabeling. Factor VII, radioiodinated by the method of Fraker and Speck (28) as modified for Factor VII by Broze (29), had a specific radioactivity of $2-4 \times 10^{3} \mathrm{cpm} / \mathrm{ng}$ and was homogeneous on SDSPAGE, migrating as a single band of radioactivity at a molecular weight of 54,000 .

Bovine antithrombin III was prepared according to Mahoney et al. (30) and was homogeneous as judged by SDS-PAGE. Radiolabeling of antithrombin III was accomplished by the lactoperoxidase method as described for Factor IX and the specific radioactivity achieved was $0.5-1.1 \times 10^{4} \mathrm{cpm} / \mathrm{ng}$. Iodinated antithrombin III comigrated with unlabeled material on SDS-PAGE.

Monospecific antisera against Factor IX, Factor VII, and antithrombin III were raised in rabbits by standard methods (31). IgG from rabbit serum was purified by use of protein A-Sepharose CL-6B (Pharmacia Fine Chemicals) according to the manufacturer's recommendations. Burro anti-bovine Factor V IgG (32) and normal burro serum were generously provided by Drs. P. Tracy and K. Mann (Mayo Clinic, Rochester, MN). Normal burro IgG was prepared from nonimmune serum as described (31). Purified IgG preparations had no detectable Factor XI, VII, IX, or X, or thrombin activity by clotting assay. Protein concentrations were determined colorimetrically (33). The concentrations of activated factors were also determined by active site titration with $p$-nitrophenyl-p'-guanidinobenzoate (34). Clotting assays were done as described previously (35) and calcium concentrations were determined with murexide (36). SDS-PAGE was carried out as 
described previously (9) except that samples of vessel bound ${ }^{125}$ I-Factors $X_{a}$ and $X_{a i}$ were prepared as follows: vessel segments with bound tracer were incubated for $20 \mathrm{~min}$ at $4^{\circ} \mathrm{C}$ with Tris-buffered saline containing 1\% Nonidet P-40 (Sigma Chemical Co., St. Louis, MO), $10 \mathrm{mM}$ EDTA, $0.5 \mathrm{mM}$ phenylmethyl sulfonyl fluoride, $2 \mathrm{mM}$ diisopropyl fluorophosphate. The vessel eluate was then prepared for SDS-PAGE as described previously. Electrophoresis standards included calibration proteins obtained from Pharmacia Fine Chemicals and complexes of ${ }^{125} \mathrm{I}$-Factor $\mathrm{X}_{\mathbf{a}}$ or ${ }^{125} \mathrm{I}$-thrombin with antithrombin III $(37,38)$ prepared by incubation of ${ }^{125}$ I-Factor $X_{a}(5 \mathrm{nM})$ or ${ }^{125}$ I-thrombin $(5 \mathrm{nM})$ with antithrombin III $(10 \mathrm{nM})$ and heparin $(1 \mathrm{U} / \mathrm{ml})$ in a final volume of $25 \mu \mathrm{l}$ for $3 \mathrm{~min}$.

Bovine aortas. Thoracic aortas, a generous gift of the Great American Veal Co. (Newark, NJ), were obtained from 1-yr-old calves within 5 min postmortem. Killing and exsanguination of the animals occurred simultaneously. Experiments were performed either immediately or after transport of the aortas to the laboratory (about $40 \mathrm{~min}$ later). During transport, aortas were stored at $21^{\circ} \mathrm{C}$ immersed in Hank's balanced salt solution (Gibco Laboratories, Gibco Div., Grand Island, NY) containing $25 \mathrm{mg} / \mathrm{ml}$ bovine serum albumin, fatty acid free (BSA-FAF). For binding and activation studies the surrounding fat was removed and aortas were cut longitudinally between the intercostal vessels into $4.5 \times 21 \mathrm{~cm}$ segments, spread flat, and placed within a Lucite template. The Lucite template consisted of two sheets of half-inch-thick Lucite. The lower sheet was solid, and the upper sheet was prepared by drilling $0.79,3.8$, or $10 \mathrm{~cm}^{2}$ holes at regular intervals. Aortic segments were placed on the lower sheet and covered with the upper sheet. The sheets fit closely together so that wells were formed by the holes in the upper sheet. These wells did not leak during the incubation period and $>98 \%$ of the added counts could be recovered. Control experiments were carried out in natural depressions in the vessel formed by resting the aorta on top of the upper sheet of the Lucite template; natural depressions of roughly the same volume as those generated by the $3.8 \mathrm{~cm}^{2}$ well area were selected. Other experiments were performed directly on lucite sheets without aortas to exclude possible artifacts due to lucite-coagulation factor interaction. Some aortas were treated with collagenase $(0.1 \%$, CLSII; Worthington Biochemical Corp., Freehold, NJ) in Dulbecco's phosphate buffered saline by incubating the luminal surface of the vessel with the enzyme preparation for $10 \mathrm{~min}$ at $37^{\circ} \mathrm{C}$. Soybean trypsin inhibitor $(0.5$ $\mathrm{mg} / \mathrm{ml}$; Sigma Chemical Co.) was added for $5 \mathrm{~min}$ at $21^{\circ} \mathrm{C}$ to neutralize tryptic activity in the collagenese preparation, and aortas were washed extensively with $10 \mathrm{ml}$ of buffer A (10 mM Hepes [pH 7.45] containing $137 \mathrm{mM} \mathrm{NaCl}, 4 \mathrm{mM} \mathrm{KCl}, 11 \mathrm{mM}$ glucose, $2.5 \mathrm{mM} \mathrm{CaCl}$, and 5 $\mathrm{mg} / \mathrm{ml}$ BSA-FAF). Binding and activation studies were then carried out as described below.

To determine if Factors IX and VII could be eluted from the aortas, the intercostal vessels and distal part of the aortic segment were clamped off, and the aorta was washed seven times at $21^{\circ} \mathrm{C}$ with buffer A. Aortas were then incubated with $5 \mathrm{ml}$ buffer B (which is buffer A with $10 \mathrm{mM}$ EDTA in place of $\mathrm{CaCl}_{2}$ ) for $1 \mathrm{~min}$. After incubation with buffer $B$ the vessel was washed again with buffer B. Where indicated, EDTA eluates were concentrated by ultrafiltration using a PM10 membrane (Amicon Corp., Lexington, MA). The amount of vessel-associated antithrombin III was determined similarly by first washing the vessel with buffer $A$, and subsequently eluting the antithrombin III with Tris-buffered saline containing $1 \%$ Nonidet P-40 for $30 \mathrm{~min}$.

Morphological study of the vessels was carried out by scanning electron microscopy using standard procedures (39).
Binding and activation studies on aortic segments. Binding studies were carried out at $21^{\circ} \mathrm{C}$. After the aorta was opened and placed beneath the template, each well was washed five times with buffer $A$ without calcium, incubated with buffer B for $30 \mathrm{~s}$, and finally washed twice with buffer $A$ in order to remove plasma and Factor IX bound in vivo from the endothelium. The integrity of the endothelium was assessed microscopically (see below). Next, $1 \mathrm{ml}$ buffer A was added to each $3.8 \mathrm{~cm}^{2}$ well, and $0.5 \mathrm{ml}$ was added to each $0.79 \mathrm{~cm}^{2}$ well. Tracer and other components of the reaction mixture, each in a volume of 10-25 $\mu$, were added, and aortas were incubated at $21^{\circ} \mathrm{C}$ for the indicated time on an orbital shaker at 30 oscillations/min. At the end of the incubation period, wells were washed five times with 1 $\mathrm{ml}$ of buffer $\mathrm{A}$ for a total of $10 \mathrm{~s}$ per well. Bound ${ }^{3} \mathrm{H}$-Factors IX/IX or ${ }^{125} \mathrm{I}$-Factors $\mathrm{X}_{\mathrm{a}} / \mathrm{X}_{\mathrm{ai}}$ were eluted by the addition of $0.5 \mathrm{ml}$ of $0.2 \mathrm{M}$ $\mathrm{NaOH} / 1 \% \mathrm{SDS} / 0.01 \mathrm{M}$ EDTA for $5 \mathrm{~min}$. Where indicated, after the initial washing of the vessel segment, wells were pre-incubated for 30$40 \mathrm{~min}$ at $21^{\circ} \mathrm{C}$ with either anti-antithrombin III, anti-Factor V, or nonimmune IgG before the addition of purified proteins. Neither nonimmune rabbit IgG nor nonimmune burro IgG affected ${ }^{125}$ I-Factor $X_{a}$ binding. Dissociation of bound ${ }^{125} I$-Factors $X_{a}$ and $X_{\mathrm{ei}}$ was measured as described by Lollar et al. (40): after the aortas were incubated with ${ }^{125} \mathrm{I}-$ Factor $\mathrm{X}_{\mathrm{a}}$ and the vessel was washed free of unbound ligand, buffer A $(0.5 \mathrm{ml} /$ well $)$ was added. At the specified times, buffer $A$ was removed, the wells were washed, and more buffer $A(0.5 \mathrm{ml})$ was added. Then the wells were washed with buffer $A$ again and the cells solubilized as described above. Activation studies were carried out at $21^{\circ} \mathrm{C}$ in wells $\left(0.79 \mathrm{~cm}^{2}\right)$ prepared with buffers $A$ and $B$ as for binding studies. To study activation of Factor $\mathrm{X}$ and prothrombin by Factors IX and VWF/Factor VIII, ${ }^{3} \mathrm{H}$-Factor IX $\mathrm{a}(1-5 \mathrm{nM})$ and VWF/Factor VIII $(2 \mathrm{U} / \mathrm{ml})$ in $0.5 \mathrm{ml}$ of buffer $A$ were equilibrated with the aorta for $30 \mathrm{~min}$. The wells were then washed five times with buffer A $(0.5$ $\mathrm{ml} /$ wash) and finally filled with $0.5 \mathrm{ml}$ of buffer A. Factor X $(0.21$ $\mu \mathrm{M})$ with or without prothrombin $(1.4 \mu \mathrm{M})$ was then added to the well. Thrombin $(0.1 \mathrm{nM})$ was added to effect rapid activation of VWF/ Factor VIII. When prothrombin activation by Factor $\mathbf{X}_{\mathbf{a}}$ was studied, wells were incubated with ${ }^{125} I$-Factor $X_{a}(3-60 \mathrm{nM})$, washed, and then prothrombin $(1.4 \mu \mathrm{M})$ was added. In the experiments using antibodies, either nonimmune burro or rabbit IgG, or anti-Factor V IgG or antiantithrombin III IgG was added to $0.5 \mathrm{ml}$ of buffer $\mathrm{A}$ and equilibrated with the aortic wells for $40 \mathrm{~min}$ at $21^{\circ} \mathrm{C}$ before the addition of clotting proteins. Samples for Factor $\mathrm{X}_{\mathbf{a}}$ and thrombin assay were obtained by the addition of $0.5 \mathrm{ml}$ buffer $\mathrm{C}(50 \mathrm{mM}$ Tris- $\mathrm{HCl}$ [pH 7.8], $175 \mathrm{mM}$ $\mathrm{NaCl}, 10 \mathrm{mM}$ EDTA, $0.5 \mathrm{mg} / \mathrm{ml}$ ovalbumin) to each well and then withdrawing $0.2 \mathrm{ml}$ for assay. Where specified, $0.1-\mathrm{ml}$ aliquots were withdrawn from reaction wells and placed in glass tubes. Buffer $\mathrm{C}(0.2$ $\mathrm{ml}$ ) was then added either immediately or after 10-20 min. Samples were assayed for Factor $\mathbf{X}_{\mathrm{a}}$ by monitoring hydrolysis of the chromogenic peptide, S-2222 (24). Thrombin was assayed (41) by the same protocol as for Factor $X_{a}$, with H-D-Phe-Pip-Arg-p-nitroanilide (S-2238) (Helena Laboratories) at $0.1 \mathrm{mM}$ final concentration. Factor $X_{a}$ inactivation studies were carried out with the S2222 assay by the method of Odegard et al. (42). Control wells incubated with $0.1 \mathrm{nM}$ of thrombin (as used for activation of VWF/Factor VIII) or with buffer alone showed no significant hydrolysis of either synthetic substrate under these conditions. The amounts of Factor $X_{a}$ and thrombin formed were determined from the linear portion of a standard curve in which known amounts of Factor $X_{a}$ or thrombin were assayed under conditions identical to the experimental samples. Although qualitatively the results were similar in each binding and activation experiment and yielded similar dose-response relationships, the base line varied by as much as 
two- to threefold from one experiment to another. Accordingly, the figures present results from representative experiments.

Radioimmunoassays for Factor IX, Factor VII, and antithrombin III. Radioimmunoassay for Factor IX antigen was carried out using a specific rabbit antiserum for bovine Factor IX generously provided by Dr. K. Fujikawa (University of Washington, Seattle, WA). The assay was carried out by the method of Suzuki and Thompson (43). The limit of detection in this assay was $1.1 \mathrm{nM}$ Factor IX antigen, which corresponded to $80 \%$ binding on the standard curve. This assay did not distinguish between Factor IX and Factor IX. The assay for Factor VII was carried out by the same protocol described for Factor IX, using a monospecific rabbit anti-bovine Factor VII antiserum. The limit of detection was $2 \mathrm{nM}$. The assay for antithrombin III using a monospecific rabbit antibody was also carried out by the same protocol except that all tubes (including the standards) had a final concentration of $0.5 \%$ Nonidet P-40. The limit of detection in this assay was $1 \mathrm{nM}$.

\section{Results}

Microscopic study of calf aortas. A continuous layer of endothelium was present on the vessels at the end of the incubation period (data not shown). Examination by scanning electron microscopy showed no evidence of cytoplasmic rupture, endothelial loss, exposure of the internal elastic laminae, or adherent platelets. The cells did, however, appear protuberant as a result of a lack of transmural pressure. Direct cell counts showed $1 \pm 0.04 \times 10^{6} \mathrm{cells} / \mathrm{cm}^{2}$ (mean $\pm 1 \mathrm{SD}$ ) vessel surface area. Aortas treated with collagenase showed total loss of endothelium.

\section{Factor IX/IXa studies}

Binding. Elution of Factor IX from bovine aortic segments was studied to assess binding of endogenous Factor IX at the time of slaughter. Eluates obtained from aortas $5 \mathrm{~min}$ postmortem were tested for Factor IX antigen by radioimmunoassay (Table I). A small amount of Factor IX antigen was observed

Table I. Elution of Coagulation Factors from Aortas

\begin{tabular}{|c|c|c|c|}
\hline & $\begin{array}{l}\text { Factor IX } \\
\text { antigen* }\end{array}$ & $\begin{array}{l}\text { Factor VII } \\
\text { antigen* }\end{array}$ & $\begin{array}{l}\text { Antithrombin } \\
\text { III antigen* }\end{array}$ \\
\hline & $\mathrm{fmol} / 10^{6} \mathrm{cells}$ & $\mathrm{fmol} / 10^{6} \mathrm{cells}$ & $\mathrm{pmol} / 10^{6} \mathrm{cells}$ \\
\hline \multicolumn{4}{|c|}{ Buffer A wash } \\
\hline 1 & $26 \pm 2$ & $19 \pm 2$ & $1.2 \pm 0.2$ \\
\hline 2 & $14 \pm 2$ & $<10$ & 0.5 \\
\hline 5 & $<11$ & $<10$ & $<0.5$ \\
\hline 7 & $<11$ & $<10$ & $<0.5$ \\
\hline \multicolumn{4}{|c|}{ Elution‡ } \\
\hline 1 & $74 \pm 8$ & $<10$ & $3.8 \pm 0.5$ \\
\hline 2 & $<11$ & $<10$ & $<0.5$ \\
\hline
\end{tabular}

* Each value is the mean of triplicates from a single experiment and the SEM is given. The experiment was repeated three times.

‡ Factors IX and VII were eluted with buffer B, which contains EDTA. Antithrombin III was eluted with Tris-buffered saline containing $1 \%$ Nonidet P-40. only in the early washes with buffer A, reflecting the presence of plasma on the vessel surface. EDTA elution yielded 74 fmol/ $10^{6}$ cells, corresponding to $\sim 45,000$ molecules of Factor IX bound per cell. The Factor IX previously eluted from 30 aortas was pooled, concentrated by ultrafiltration, recalcified, and assayed for Factor $\mathrm{IX}_{\mathrm{a}}$ activity in a clotting assay where the lowest detectable Factor $\mathrm{IX}_{\mathrm{a}}$ concentration was $100 \mathrm{pM}$. At a Factor IX antigen concentration of $15 \mathrm{nM}$, no Factor IX $_{\mathrm{a}}$ clotting activity could be detected. As a control for the specificity of Factor IX binding, the EDTA eluates were tested for the presence of Factor VII antigen. Although this antigen could be detected in the initial wash, no Factor VII could be detected in the EDTA eluate (Table I) or in the 50-fold concentrated eluate pooled from 30 aortas.

Binding of Factors IX and IX $\mathrm{X}_{\mathrm{a}}$ to vessel segments, washed with calcium-free buffer to remove endogenously bound Factor IX, was then examined. The parameters of Factor IX and IX binding were quite comparable to those previously observed using cultured bovine aortic endothelial cells (9). Binding was specific for Factors IX and IX $\mathrm{I}_{\mathrm{a}}$, reversible (50\% of bound Factor IX eluted in $10 \mathrm{~min}$ ), calcium dependent (reaching a plateau by $2.5 \mathrm{mM}$ ), and saturable (half-maximal at a total added Factor IX concentration of $2.6 \mathrm{nM}$ ). Binding of ${ }^{3} \mathrm{H}$-Factor IX IX $\mathrm{IX}_{\mathrm{a}}$ could be inhibited by a 100 -fold molar excess of either unlabeled Factor IX $\mathrm{I}_{\mathrm{a}}$ or Factor IX. At an added ${ }^{3} \mathrm{H}$-Factor IX concentration of $2.6 \mathrm{nM}$, binding was half-maximal and total vessel binding was $2.2-2.9 \%$ of the added tracer. The nonspecific binding was $16-19 \%$ of the total binding (0.4-0.5\% of the added tracer).

Activation. Vessel-bound ${ }^{3} \mathrm{H}$-Factor IXa in the presence of VWF/Factor VIII activated added Factor $\mathrm{X}$ (Fig. $1 A$ ). If unactivated VWF/Factor VIII was added in place of the thrombin-treated VWF/Factor VIII, Factor $\mathrm{X}$ activation occurred though there was a slightly longer lag (2-3 min with unactivated Factor VIII as compared with 1-1.5 min with activated Factor VIII) before Factor $\mathrm{X}_{\mathrm{a}}$ activity was detected. When prothrombin was added along with Factors VIII and X, vessel-bound ${ }^{3} \mathrm{H}$-Factor $\mathrm{IX}_{\mathrm{a}}$ initiated a series of reactions leading to thrombin formation (Fig. $1 C$ ). Unlabeled Factor IXa promoted activation of Factor $\mathrm{X}$ and prothrombin under the same conditions. Interaction of coagulation factors with the endothelium was essential for Factor $X_{a}$ and thrombin formation, as no activation was observed when the proteins were mixed on a Lucite plate in the absence of an aortic segment or when collagenase-treated vessel segments devoid of endothelium replaced the intact segments. Furthermore, when an aliquot of the reaction mixture was removed from the reaction well and incubated in a glass tube, no additional activation of Factor $\mathrm{X}$ or prothrombin occurred. The amount of Factor $\mathrm{X}_{\mathrm{a}}$ formed in 10 min was correlated with the amount of ${ }^{3} \mathrm{H}$-Factor IX $\mathrm{X}_{\mathrm{a}}$ specifically bound to the aorta (Fig. $1 \mathrm{~A}$ ). Omission of Factor IX $\mathrm{X}_{\mathrm{a}}, \mathrm{VWF} /$ Factor VIII substitution of Factor IX for Factor IX $_{\mathrm{a}}$, or elution of specifically bound ${ }^{3} \mathrm{H}$-Factor $\mathrm{IX}_{\mathbf{a}}$ with calcium-free buffer prevented Factor $\mathbf{X}_{\mathrm{a}}$ 

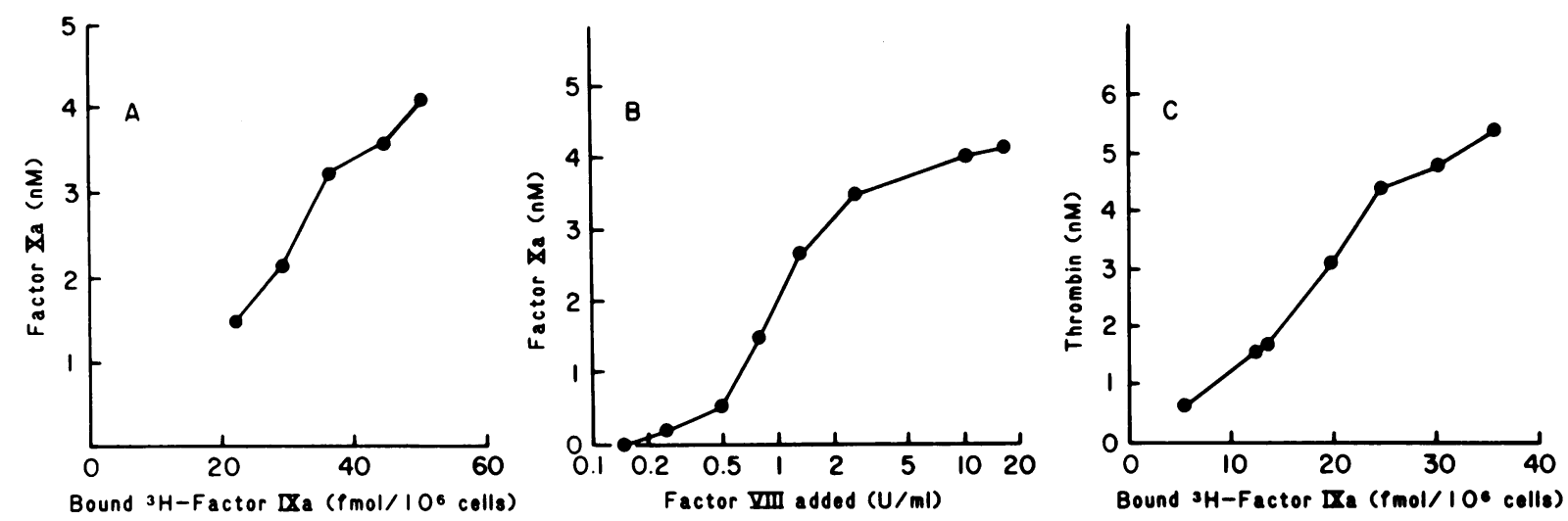

Figure 1. Activation of Factor $\mathrm{X}$ and prothrombin by Factor $\mathrm{IX}_{\mathrm{a}}$ and VWF/Factor VIII on aortic segments. $(A)$ Dependence of Factor $\mathrm{X}_{\mathrm{a}}$ formation on bound Factor IX $\mathrm{X}_{\mathrm{a}} \cdot{ }^{3} \mathrm{H}-$ Factor IX $\mathrm{a}(1-5 \mathrm{nM})$ and VWF/ Factor VIII $(2 \mathrm{U} / \mathrm{ml}), 10 \mu \mathrm{l}$ each, were added to wells containing 0.5 $\mathrm{ml}$ buffer $\mathrm{A}$ and incubated for $10 \mathrm{~min}$. After aspiration and washing, $0.5 \mathrm{ml}$ buffer $A$ and $10 \mu \mathrm{l}$ each of thrombin $(0.1 \mathrm{nM})$ and Factor $X$ $(0.21 \mu \mathrm{M})$ were added and followed by a $10-\mathrm{min}$ incubation. Then $0.5 \mathrm{ml}$ buffer $\mathrm{C}$ was added to each well, and a $0.2-\mathrm{ml}$ aliquot of the supernatant was removed for the $\mathrm{S}-2222$ synthetic substrate assay. Specific ${ }^{3} \mathrm{H}$-Factor IX $\mathrm{X}_{\mathrm{a}}$ binding was determined from the difference between the binding observed in wells incubated with ${ }^{3} \mathrm{H}$-Factor $\mathrm{IX}_{\mathrm{a}}$ alone and the binding observed in wells incubated with ${ }^{3} \mathrm{H}$-Factor $\mathrm{IX}_{\mathrm{a}}$ in the presence of a 100 -fold molar excess of unlabeled factor $\mathrm{IX}_{\mathrm{a}}$. The concentration of Factor $\mathrm{X}_{\mathrm{a}}$ formed is plotted against specifically bound ${ }^{3} \mathrm{H}$-Factor $\mathrm{IX}_{\mathrm{a}}$. (B) Dependence of Factor $\mathrm{X}_{\mathrm{a}}$ formation on VWF/Factor VIII concentration. ${ }^{3} \mathrm{H}$-Factor $\mathrm{IX}_{\mathrm{a}}(3.8 \mathrm{nM})$ and

formation. In addition, the inclusion of a 500 -fold molar excess of Factor IX in each initial incubation mixture in Fig. $1 \mathrm{~A}$ blocked Factor $\mathrm{X}$ activation and specific ${ }^{3} \mathrm{H}$-Factor $\mathrm{IX}_{\mathrm{a}}$ binding by $>90 \%$. The amount of Factor $X_{a}$ formed could also be correlated with the concentration of exogenous VWF/ Factor VIII (Fig. $1 B$ ) added. The retention of Factor VIII activity on the aorta after washing of the vessel suggests that Factor VIII bound to the vessel wall. Thrombin formation initiated by cell-bound ${ }^{3} \mathrm{H}$-Factor $\mathrm{IX}_{\mathrm{a}}$ occurred only in presence of VWF/Factors VIII, $X$, and prothrombin and correlated well with the amount of specifically bound ${ }^{3} \mathrm{H}$-Factor $\mathrm{IX}_{\mathrm{a}}(\mathrm{Fig}$. C).

\section{Factor $X_{a}$ studies}

Binding. Incubation of ${ }^{125} \mathrm{I}$-Factor $\mathrm{X}_{\mathrm{a}}$ with bovine aortic segments resulted in progressive loss of Factor $\mathrm{X}_{\mathrm{a}}$ activity in the supernatant (Fig. $2 \mathrm{~A}$ ). When aliquots of the incubation mixture were removed at various times and analyzed by SDS-PAGE, the radioactivity profile showed formation of a new slowly migrating peak (labeled $\mathrm{X}_{\mathrm{a}}$-ATIII in Fig. 2, $B$ and $C$ ). After a 1-min incubation of Factor $X_{a}$ with the vessel segment (Fig. 2 $B$ ), $49 \%$ of the initial Factor $X_{a}$ activity was lost and $46 \%$ of the added Factor $X_{a}$ was present in the higher molecular weight peak. After a 28-min incubation of ${ }^{125}$ I-Factor $X_{a}$ with the vessel segment (Fig. 2 C), 94\% of the initial Factor $X_{a}$ activity was lost and $90 \%$ of the added Factor $X_{a}$ was present in the peak labeled $\mathrm{X}_{\mathrm{a}}$-ATIII. This high molecular weight peak

varying amounts of VWF/Factor VIII $(0.15-17 \mathrm{U} / \mathrm{ml})$ each in a volume of $15 \mu$ l were added to $0.5 \mathrm{ml}$ of buffer $A$ in $0.79 \mathrm{~cm}^{2}$ wells and incubated for $10 \mathrm{~min}$ at $21^{\circ} \mathrm{C}$. After aspiration and washing, Factor $\mathrm{X}$ and thrombin were added and the procedure was carried out as in $A$. $(C)$ Activation of prothrombin. Aortic segments were incubated with ${ }^{3} \mathrm{H}$-Factor $\mathrm{IX}_{\mathrm{a}}$ and $\mathrm{VWF} /$ Factor VIII $(2 \mathrm{U} / \mathrm{ml})$, then washed as described above. Next, $10 \mu$ lof prothrombin $(1.4 \mu \mathrm{M})$ was added along with Factor $\mathrm{X}$ and thrombin $(0.1 \mathrm{nM})$. The remainder of the procedure was identical to that described in $A$ except that $\mathrm{S}$ 2238 was used in the synthetic substrate assay. The amount of specifically bound ${ }^{3} \mathrm{H}$-Factor $\mathrm{IX}_{\mathrm{a}}$ is plotted against thrombin formed. In $A-C$ above each point is the mean of duplicate wells from a single representative experiment. The experiments were repeated four times and in each case not more than $3 \%$ of the available substrate was activated.

represented ${ }^{125} \mathrm{I}$-Factor $\mathrm{X}_{\mathrm{a}}$ complexed with antithrombin III since it comigrated with the ${ }^{125}$ I-Factor $\mathrm{X}_{\mathrm{a}}$-antithrombin III standard and its formation could be blocked by $>\mathbf{9 0 \%}$ when vessel segments were pre-incubated with anti-antithrombin III $\operatorname{IgG}(600 \mu \mathrm{g} / \mathrm{ml})$. Since no antithrombin III was added to these incubation mixtures, it seemed possible that the source of this protein was vessel-associated antithrombin III. To confirm this, vessel segments were washed with buffer $A$ until no further antithrombin III antigen could be detected and then eluted with Tris-buffered saline containing 1\% Nonidet P-40. The amount of antithrombin III antigen eluted from the vessel wall corresponded to $3.8 \pm 0.5 \mathrm{pmol} / 10^{6}$ cells (Table I).

Association of ${ }^{125} \mathrm{I}$-Factor $\mathrm{X}_{\mathrm{a}}$ with the vessel was then examined. ${ }^{125}$ I-Factor $\mathrm{X}_{\mathrm{a}}$ bound in a time-dependent manner to the vessel segment, and the amount of specifically bound ${ }^{125}$ I-Factor $\mathrm{X}_{\mathrm{a}}$ (Fig. 3) increased markedly in the presence of anti-antithrombin III IgG and decreased slightly in the presence of added antithrombin III. Binding of ${ }^{125} \mathrm{I}$-Factor $\mathrm{X}_{\mathrm{a}}$ in the absence of nonimmune $\operatorname{IgG}$ (not shown) was identical to that shown in the presence of nonimmune IgG. Furthermore, antiantithrombin III IgG prevented complex formation between ${ }^{125} \mathrm{I}$-Factor $\mathrm{X}_{\mathrm{a}}$ and antithrombin III. These data suggested that complex formation between ${ }^{125} \mathrm{I}$-Factor $\mathrm{X}_{\mathrm{a}}$ and antithrombin III prevented binding of Factor $X_{a}$ to the vessel. Vessel binding of ${ }^{125} \mathrm{I}$-Factor $\mathrm{X}_{\mathrm{ai}}$, which cannot complex with antithrombin III, was substantially greater than binding of ${ }^{125}$ I-Factor $X_{a}$ 

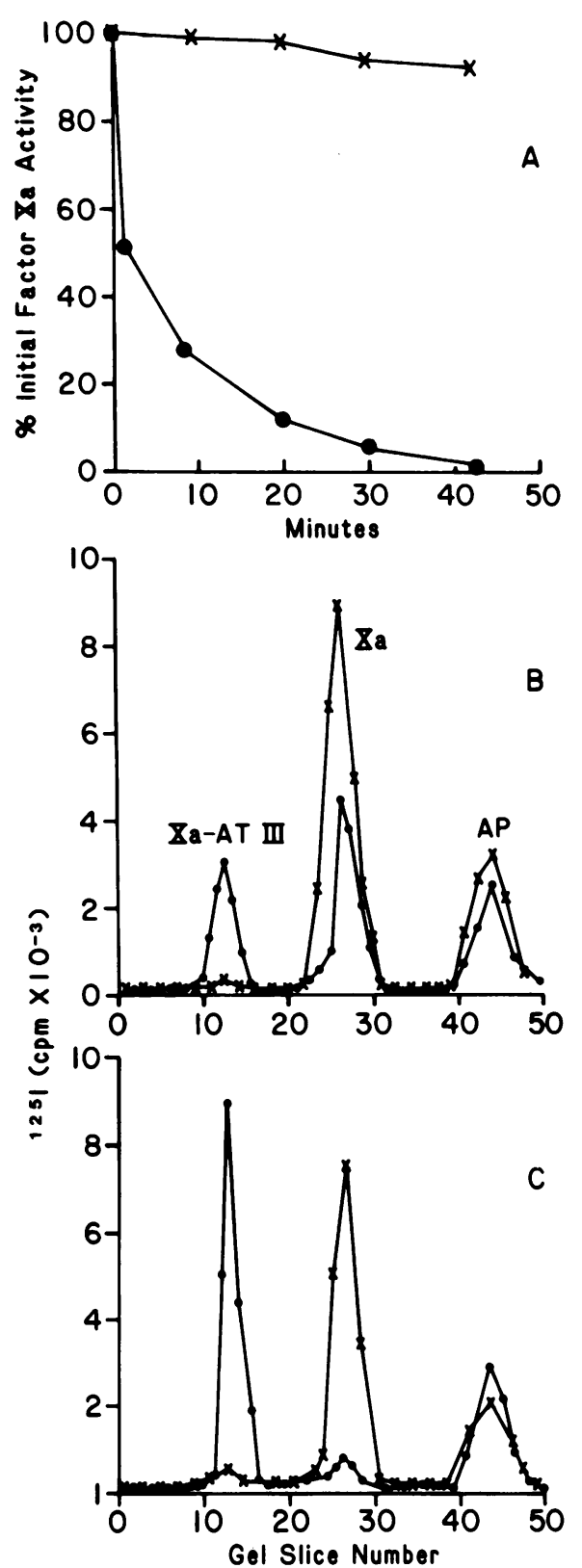

Figure 2. Inactivation of ${ }^{125} \mathrm{I}$-Factor $\mathrm{X}_{\mathrm{a}}$ in the supernatant incubated with bovine aortic segments. Aortic wells were incubated with antiantithrombin III IgG $(x)$ or nonimmune IgG $(\bullet)$, each at $600 \mu \mathrm{g} / \mathrm{ml}$ for 40 min. $(A){ }^{125} \mathrm{I}$-Factor $\mathrm{X}_{\mathrm{a}}(11 \mathrm{nM})$ was added and Factor $\mathrm{X}_{\mathrm{a}}$ inactivation was assessed by chromogenic substrate assay at the indicated times (see text). In $B$ and $C$, aliquots of supernatant were subjected to nonreduced 7.5\% SDS-PAGE. The incubation times were 1 and $28 \mathrm{~min}$ in $B$ and $C$, respectively. Labeled peaks correspond to Factor $\mathrm{X}_{\mathrm{a}}$-antithrombin III complex $\left(\mathrm{X}_{\mathrm{a}}-\mathrm{AT}\right.$ III), Factor $\mathrm{X}_{\mathrm{a}}$, and activation peptide (AP)

and was not affected by the presence of the antithrombin III antibody or addition of exogenous antithrombin III. In addition, when vessel segments were pre-incubated with thrombin, bind- ing of ${ }^{125} \mathrm{I}$-Factor $\mathrm{X}_{\mathrm{a}}$ (Fig. 3), but not of ${ }^{125} \mathrm{I}$-Factor $\mathrm{X}_{\mathrm{ai}}$, was increased. However, specific binding of Factor $X_{a}$ remained somewhat less than in the presence of anti-antithrombin III IgG. The effect of thrombin on the binding of ${ }^{125}$ I-Factor $X_{a}$ was due to complex formation between thrombin and antithrombin III, since when thrombin was added in the presence of antithrombin III antibody (which could partially block thrombin-antithrombin III complex formation) there was no further enhancement of ${ }^{125} \mathrm{I}$-Factor $\mathrm{X}_{\mathrm{a}}$ binding. The inability of thrombin, even at higher concentrations, to enhance binding to as great an extent as antibody to antithrombin III may be due to multiple interactions of thrombin with the cells in addition to complexing with vessel-associated antithrombin III.

Comparison of the vessel binding of ${ }^{125} \mathrm{I}$-Factors $\mathrm{X}_{\mathrm{a}}$ and $\mathrm{X}_{\mathrm{ai}}$ (Fig. $4 A$ ) showed that the time course of ${ }^{125} \mathrm{I}$-Factor $\mathrm{X}_{\mathrm{a}}(1$ $\mathrm{nM})$ binding appeared biphasic, consisting of a more rapid initial phase which was complete within 3-4 min and a steadily increasing slower component. The initial phase of ${ }^{125} \mathrm{I}$-Factor $\mathbf{X}_{\mathrm{a}}$ binding was identical to Factor $\mathbf{X}_{\mathrm{a}}$ binding. However, in contrast to ${ }^{125} \mathrm{I}$-Factor $\mathrm{X}_{\mathrm{a}}$, the binding of ${ }^{125} \mathrm{I}$-Factor $\mathrm{X}_{\mathrm{ai}}$ (1 $\mathrm{nM}$ ) reached an apparent maximum after $4 \mathrm{~min}$ and did not change later. Binding of ${ }^{125} \mathrm{I}$-Factor $\mathrm{X}_{\mathrm{a}}$, which was allowed to proceed for only $3 \mathrm{~min}$, was largely reversible (Fig. $4 \mathrm{~A}$ ). The dissociation of bound ${ }^{125} \mathrm{I}$-Factors $\mathrm{X}_{\mathrm{a}}$ and $\mathrm{X}_{\mathrm{ai}}$ was $50 \%$ complete by $7 \mathrm{~min}$ for each protein. After $18 \mathrm{~min}$ of incubation with the vessel the amount of dissociable ${ }^{125} \mathrm{I}$-Factors $\mathrm{X}_{\mathrm{a}}$ and $\mathrm{X}_{\mathrm{ai}}$ remained the same, though the total amount of bound ${ }^{125} \mathrm{I}$-Factor $\mathrm{X}_{\mathrm{a}}$ had increased owing to formation of a pool of covalently bound ${ }^{125} \mathrm{I}$-Factor $\mathrm{X}_{\mathrm{a}}$ (see below). From Fig. $4 \mathrm{~A}$ it appeared that after 3-4 min of incubation, the binding of ${ }^{125} \mathrm{I}$-Factor $\mathrm{X}_{\mathrm{a}}$ in the presence of antibody to antithrombin III and ${ }^{125} \mathrm{I}-\mathrm{Factor} \mathrm{X}_{\mathrm{ai}}$ were quite similar. Semilogarithmic plots

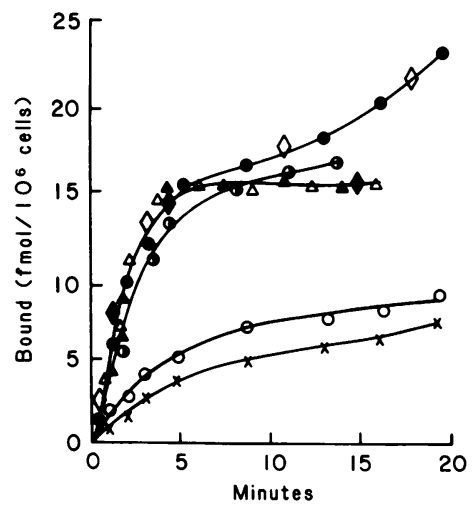

Figure 3. Time course of ${ }^{125}$ I-Factors $\mathrm{X}_{\mathrm{a}}$ and $\mathrm{X}_{\mathrm{ai}}$ binding: the effect of exogenous antithrombin III, antibody to antithrombin III, and thrombin. Aortic wells were incubated with either anti-antithrombin III IgG $(550 \mu \mathrm{g} / \mathrm{ml} ; \bullet)$, nonimmune IgG $(600 \mu \mathrm{g} / \mathrm{ml} ; 0)$, buffer alone $(\diamond)$, thrombin $(1.80 \mathrm{nM} ; 0)$, or added antithrombin III $(2.7 \mu \mathrm{M} ; x)$ for $30 \mathrm{~min}$. Then ${ }^{125} \mathrm{I}-\mathrm{Fac}$ tor $\mathrm{X}_{\mathrm{a}}(0.9 \mathrm{nM})$ was added alone (total binding), or with unlabeled Factor $\mathrm{X}_{\mathrm{a}}(480 \mathrm{nM})$ (nonspecific binding). Other wells were pre-incubated with the same amount of anti-antithrombin III $\operatorname{IgG}(\Delta)$, or buffer alone $(\bullet)$, or nonimmune $\operatorname{IgG}(\Delta)$ for $30 \mathrm{~min}$, and then ${ }^{125} \mathrm{I}-$ Factor $X_{\mathrm{ai}}(1 \mathrm{nM})$ alone or with unlabeled Factor $X_{\mathrm{ai}}(360 \mathrm{nM})$ was added. Nonspecific binding was $19-22 \%$ of the total binding. Each point is the mean of duplicate measurements, and the experiment was repeated three times. 


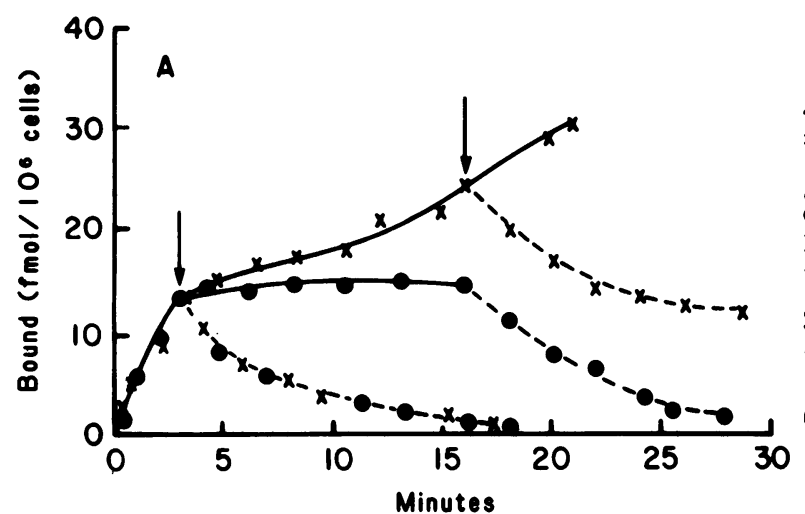

Figure 4. (A) Time course and reversibility of specific ${ }^{125} \mathrm{I}$-Factor $\mathrm{X}_{\mathrm{a}}$ $(x)$ or $\mathrm{X}_{\mathrm{aj}}(\bullet)$ binding to aortic segments. Aortic wells were pre-incubated with anti-antithrombin III IgG $(600 \mu \mathrm{g} / \mathrm{ml})$ for $30 \mathrm{~min}$ in 0.5 $\mathrm{ml}$ of buffer $\mathrm{A}$; then ${ }^{125} \mathrm{I}$-Factor $\mathrm{X}_{\mathrm{a}}(1 \mathrm{nM})$ alone (total binding) or with $0.5 \mu \mathrm{M}$ unlabeled Factor $\mathrm{X}_{\mathrm{a}}$ (nonspecific binding), or ${ }^{125} \mathrm{I}$-Factor $\mathrm{X}_{\mathrm{ai}}(1 \mathrm{nM})$ alone or with unlabeled Factor $\mathrm{X}_{\mathrm{ai}}(0.6 \mu \mathrm{M})$ was added to other wells. Dissociation studies were carried out as described in Methods starting at 3 and $18 \mathrm{~min}$ as indicated by the arrows. Solid lines show the time course of binding and broken lines show dissociation. $(B)$ Saturability of specific ${ }^{125} \mathrm{I}-$ Factors $\mathrm{X}_{\mathrm{a}}(\bullet)$ and $\mathrm{X}_{\mathrm{ai}}(\mathrm{x})$ binding to bovine aortic segments. Aortas $\left(0.79 \mathrm{~cm}^{2}\right.$ wells $)$ were pre-

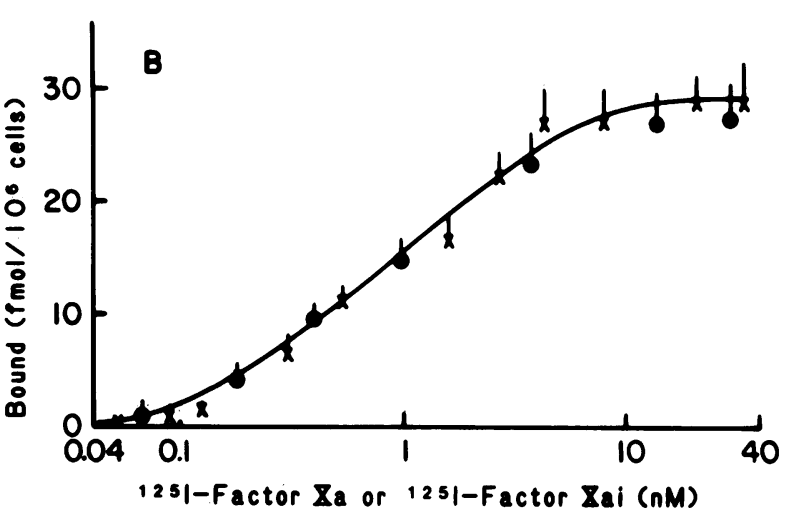

incubated with anti-antithrombin III IgG $(600 \mu \mathrm{g} / \mathrm{ml})$ for $40 \mathrm{~min}$ in $0.5 \mathrm{ml}$ buffer $\mathrm{A}$. Then the indicated amount of ${ }^{125} \mathrm{I}$-Factor $\mathrm{X}_{\mathrm{a}}$ or $\mathrm{X}_{\mathrm{ai}}$ was added to one set of wells, and tracer together with a 100-fold molar excess of unlabeled protein was added to another set of wells. Incubation times were 4 and 20 min for ${ }^{125}$ I-Factors $X_{a}$ and $X_{a i}$, respectively. Each point is the mean of triplicates and in $B$ the SEM is shown. The experiments were repeated five times. At an added ${ }^{125} \mathrm{I}$-Factor $\mathrm{X}_{\mathrm{a}}$ or $\mathrm{X}_{\mathrm{ai}}$ concentration of $0.9 \mathrm{nM}$, binding was halfmaximal in these experiments and total vessel binding was $\sim 4 \%$ of the added tracer.

and 63,000 on reduced (V') SDS-PAGE. The vessel-bound complex had a different molecular weight on unreduced SDSPAGE $(76,000)$ than did the Factor $X_{a}$-antithrombin III complex found in the supernatant $(84,000)$ (Fig. 2). Also, formation of the vessel bound complex was not blocked by anti-antithrombin III IgG. ${ }^{125} \mathrm{I}$-Factor $\mathrm{X}_{\mathrm{a}}$-vessel wall complexes, solubilized in Nonidet P-40 (1\%) could not be immunoprecipitated with anti-antithrombin III IgG under conditions that immunoprecipitated Factor $\mathrm{X}_{\mathrm{a}}$-antithrombin III complexes.

Reversibility studies (Fig. $4 \mathrm{~A}$ ) showed that the same amount of ${ }^{125} \mathrm{I}$-Factor $\mathrm{X}_{\mathrm{a}}$ dissociated at $3 \mathrm{~min}$ of incubation, when no covalent Factor $X_{a}$-vessel wall complex $\left(M_{r} 76,000\right)$ had formed, and at $18 \mathrm{~min}$ of incubation, when the latter complex had formed. The amount of nondissociable bound ${ }^{125} \mathrm{I}$-Factor $\mathrm{X}_{\mathrm{a}}$ increased from 3 to $18 \mathrm{~min}$ of incubation in parallel with formation of the $M_{r} 76,000$ complex. Unreduced SDS-PAGE showed that the radioactivity profile of the dissociated ${ }^{125} \mathrm{I}$ Factor $X_{a}$, in the presence of anti-antithrombin III IgG (500 $\mu \mathrm{g} / \mathrm{ml}$ ), was identical to that of the initial tracer. Factor $X_{a}$ in the 76,000 mol wt complex remained vessel associated (data not shown). The ${ }^{125} I$-Factor $X_{a}$-vessel wall complex $\left(M_{r} 76,000\right)$ thus accounts for the steadily increasing phase of irreversible binding.

Competitive binding studies carried out in the presence of antibody to antithrombin III (Fig. 6) showed no significant inhibition of ${ }^{125} \mathrm{I}$-Factor $\mathrm{X}_{\mathrm{a}}$ binding by Factors IX, IX $\mathrm{a}_{\mathrm{a}}, \mathrm{X}$, prothrombin, thrombin, or protein $\mathrm{C}$. The experiment in Fig. 6 was carried out with a 20-min incubation of coagulation proteins with the vessel, and $\sim 50 \%$ of the bound ${ }^{125}$ I-Factor $X_{\mathrm{a}}$ was in the $M_{r} \mathbf{7 6 , 0 0 0}$ complex. Competitive binding studies 


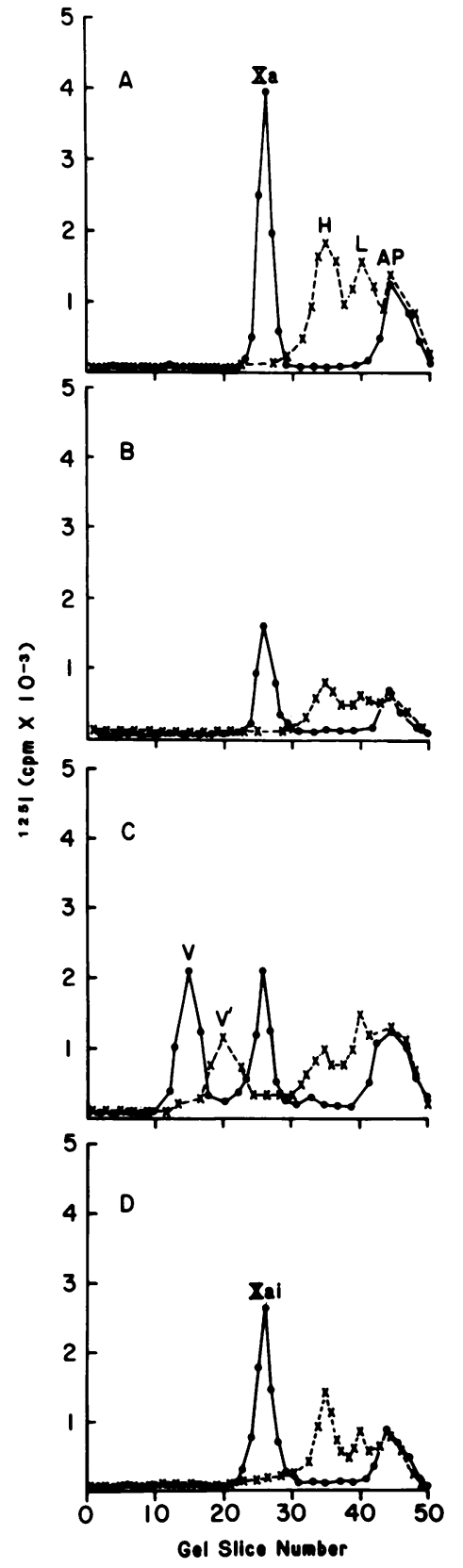

Figure 5. SDS-PAGE (7.5\%) of ${ }^{125}$ I-Factors $X_{a}$ and $\mathrm{X}_{\mathrm{ai}}$ bound to bovine aortic segments at different times. Aortic wells were pre-incubated with anti-antithrombin III IgG $(600$ $\mu \mathrm{g} / \mathrm{ml})$ and then ${ }^{125} \mathrm{I}-$ Factor $X_{\mathrm{a}}(5 \mathrm{nM})$ or $\mathrm{X}_{\mathrm{ai}}$ was added. After the indicated incubation time wells were washed with buffer $A$ and bound ${ }^{125} \mathrm{I}$-Factor $\mathrm{X}_{\mathrm{a}}$ or $\mathrm{X}_{\mathrm{ai}}$ was solubilized with $1 \%$ Nonidet P-40. Labeled peaks are designed as follows: $\mathrm{Xa},{ }^{125} \mathrm{I}$-Factor $\mathrm{X}_{\mathrm{a}}$; $X a i,{ }^{125} \mathrm{I}-$ Factor $\mathrm{X}_{\mathrm{ai}} ; \mathrm{L}$ and $\mathrm{H},{ }^{125}$ I-Factor $\mathrm{X}_{\mathrm{a}}$ light and heavy chain, respectively; AP, activation peptide; $V$, complex of bound ${ }^{125} \mathrm{I}$-Factor $\mathrm{X}_{\mathrm{a}}$ and vessel wall binding site $\left(M_{r} 76,000\right.$ unreduced); $V^{\prime}$, same complex as $\mathrm{V}$ but reduced $\left(\mathrm{M}_{\mathrm{r}}\right.$ 63,000); $\bullet$, unreduced; $x$, reduced. $(A){ }^{125} \mathrm{I}$-Factor $\mathrm{X}_{\mathrm{a}}$, no aorta; $(B){ }^{125} \mathrm{I}$-Factor $\mathrm{X}_{\mathrm{a}}$ after a 2-min incubation with aorta; $(C){ }^{125} \mathrm{I}-$ Factor $\mathrm{X}_{\mathrm{a}}$ after a 30-min incubation with aorta; $(D)$

${ }^{125} \mathrm{I}$-Factor $\mathrm{X}_{\mathrm{ai}}$ after a 30 $\min$ incubation with aorta.

were also carried out with a 4-min incubation, when $>90 \%$ of the Factor $\mathrm{X}_{\mathrm{a}}$ was reversibly bound, and at $90 \mathrm{~min}$, when $\sim 80 \%$ of the Factor $X_{a}$ was in the $M_{r} 76,000$ complex. In each case, the other cogulation proteins did not inhibit ${ }^{125} \mathrm{I}$-Factor $\mathrm{X}_{\mathrm{a}}$-vessel wall binding. Binding of ${ }^{125} \mathrm{I}$-Factor $\mathrm{X}_{\mathrm{a}}$ was calcium dependent, maximal at $3 \mathrm{mM} \mathrm{Ca}^{++}$, and decreased by $20-30 \%$ from 3 to $10 \mathrm{mM} \mathrm{Ca}^{++}$.

Activation. Prothrombin activation studies were performed on aortic segments to assess the coagulant activity of bound ${ }^{125} I$-Factor $X_{a}$. Vessel-bound ${ }^{125} I$-Factor $X_{a}$ activated added prothrombin as measured by increasing levels of amidolytic

activity in the S2238 assay (Fig. 7). Thrombin formation depended upon the presence of Factors $X_{a}$ and prothrombin, as well as on the binding of ${ }^{125} \mathrm{I}$-Factor $\mathrm{X}_{\mathrm{a}}$ to the endothelium, since no activation of prothrombin by Factor $\mathrm{X}_{\mathrm{a}}$ was observed on aortic segments previously treated with collagenase. Furthermore, when aliquots of the reaction mixture supernatant were withdrawn from contact with the endothelium at intervals and incubated in a test tube, no further thrombin formation occurred. The amount of thrombin formed on aortic segments was correlated with the amount of bound ${ }^{125} \mathrm{I}$-Factor $\mathrm{X}_{\mathrm{a}}$ (Fig. 7) and depended upon the interaction of Factor $X_{a}$ with an endothelial cell Factor V-like molecule, as shown by $75-90 \%$ inhibition of prothrombin activation in the presence of antiFactor V IgG (Fig. 7), though this concentration of antibody blocked ${ }^{125} \mathrm{I}$-Factor $\mathrm{X}_{\mathrm{a}}$ binding by only $10-30 \%$ (data not shown). The effect of anti-antithrombin III IgG on the activation of prothrombin by vessel-bound ${ }^{125} \mathrm{I}$-Factor $\mathrm{X}_{\mathrm{a}}$ was studied by comparing the amount of thrombin generation in the supernatant of wells incubated with anti-antithrombin III IgG or nonimmune IgG (Fig. 8). In the presence of antiantithrombin III IgG $(600 \mu \mathrm{g} / \mathrm{ml})$, formation of Factor $\mathrm{X}_{\mathrm{a}}$-antithrombin III complex was inhibited by $90-95 \%$ and formation of thrombin-antithrombin III complex was inhibited by $\sim 70 \%$ as judged by SDS-PAGE of reaction mixtures. Wells pre-incubated with anti-antithrombin III IgG (Fig. $8 \mathrm{~A}$ ) showed 30-50-fold more thrombin activity in the supernatant. The apparent increase in thrombin activity correlated well with the dose of anti-antithrombin III IgG and reached a plateau at $500-800 \mu \mathrm{g} / \mathrm{ml}$ of added antibody (Fig. $8 \mathrm{~B}$ ). In this range of antibody concentration, complex formation between antithrombin III and the two proteases was not blocked further by addition of more IgG (data not shown).

\section{Discussion}

These studies were initiated to examine the interaction of bovine Factors IX, IX $\mathrm{X}_{\mathrm{a}}$, and $\mathrm{X}_{\mathrm{a}}$ with a continuous layer of native endothelium. Previously it has been reported that Factors IX, IX $\mathrm{X}_{\mathrm{a}}$, and $\mathrm{X}_{\mathrm{a}}$ bind to cultured bovine aortic endothelial cells (8-13). Bound Factor IX $\mathrm{I}_{\mathrm{a}}$ can activate Factor $X$ in the presence of VWF/Factor VIII (10) and Factor $X_{a}$ can activate prothrombin when the cultured cells are subconfluent (14). Factor V synthesis by cultured endothelial cells has also been reported (44). Since endothelial cells are generally considered to inhibit hemostasis and thrombosis, we have investigated whether these clot-promoting phenomena observed with cultured cells can also be found with native endothelial cells. In an in vivo system, Factor $\mathrm{X}_{\mathrm{a}}$ binding to mouse aortas has been observed (45). In our studies the source of native endothelium was calf aortas because of the relative ease of obtaining and handling aortic tissue.

The presence of Factor IX antigen in the EDTA-eluates from vessels harvested immediately after slaughter (Table I) strongly suggests that there is Factor IX binding in vivo and supports previous observations of Factor IX binding to endo- 


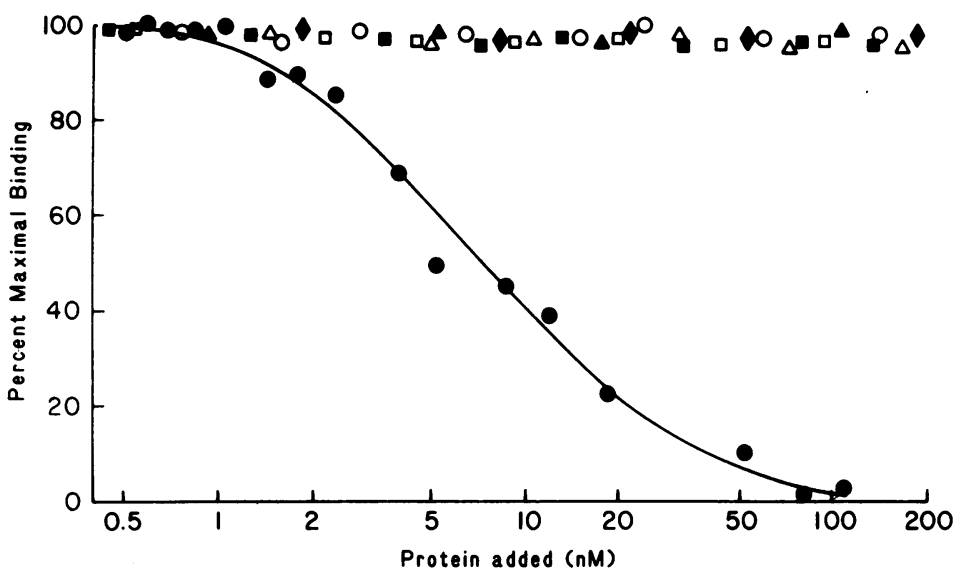

Figure 6. Competitive binding studies. Aortic segments (0.79 $\mathrm{cm}^{2}$ wells) were pre-incubated with anti-antithrombin III $\operatorname{IgG}(600 \mu \mathrm{g} / \mathrm{ml})$ for $40 \mathrm{~min}$ in buffer $\mathrm{A}(0.5 \mathrm{ml})$. Then ${ }^{125} \mathrm{I}$-Factor $\mathrm{X}_{\mathrm{a}}(1 \mathrm{nM})$ alone or the same amount of ${ }^{125} \mathrm{I}$ Factor $X_{a}$ in the presence of increasing concentrations of unlabeled Factor $X_{a}(\bullet)$, Factor $X(0)$, Factor IX (口), Factor IX $_{\mathrm{a}}(\boldsymbol{(})$, prothrombin $(\Delta)$, thrombin $(\Delta)$, or protein $\mathrm{C}(\bullet)$ was added for $20 \mathrm{~min}$. Wells were then washed and solubilized as described. Maximal binding ( $23 \mathrm{fmol} / 10^{6}$ cells) was defined as the amount of ${ }^{125} \mathrm{I}$-Factor $\mathrm{X}_{\mathrm{a}}$ bound when ${ }^{125} \mathrm{I}$ Factor $\mathrm{X}_{\mathrm{a}}$ was incubated with aortic segments alone minus the amount of ${ }^{125} \mathrm{I}$-Factor $\mathrm{X}_{\mathrm{a}}$ bound in the presence of a 100-fold molar excess of unlabeled Factor $X_{a}$. The mean of duplicates is plotted and the experiment was repeated three times. thelial cells in culture. Animals slaughtered according to kosher dietary laws were selected for these studies because in this procedure the blood drains rapidly from the aorta at the time of slaughter. Although the radioimmunoassay for Factor IX could not distinguish the zymogen from its activated form, clotting assays indicated that $<3 \%$ of the eluted Factor IX antigen was Factor $\mathbf{I X}_{\mathrm{a}}$. This suggests that Factor IX binding in vivo was responsible for Factor IX antigen in the EDTA eluate, rather than selective Factor $\mathrm{IX}_{\mathrm{a}}$ binding accompanying activation of the coagulation system at the time of slaughter. However, killing of animals by any technique certainly could

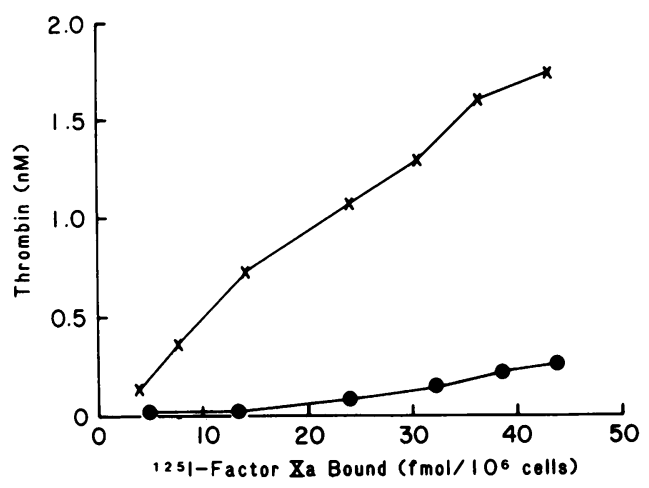

Figure 7. Activation of prothrombin by Factor $\mathrm{X}_{\mathrm{a}}$ on aortic segments. Wells $\left(0.79 \mathrm{~cm}^{2}\right)$ were preincubated with either $5 \mathrm{ml}(200$ $\mu \mathrm{g} / \mathrm{ml}$ ) of anti-Factor V IgG ( $\bullet$ ) or control burro $\mathrm{IgG}(\times)$ for $\mathbf{4 0 ~} \mathrm{min}$. ${ }^{125} \mathrm{I}$-Factor $\mathrm{X}_{\mathrm{a}}(5 \mu \mathrm{l} ; 3-30 \mathrm{nM})$ was then added to the wells and incubated for $5 \mathrm{~min}$. Unbound ${ }^{125} \mathrm{I}$-Factor $\mathrm{X}_{\mathrm{a}}$ was removed by washing with buffer $A$, and $0.5 \mathrm{ml}$ of buffer $A$ containing either antiFactor V IgG or control IgG was added to each well. The same IgG as for the initial incubation followed by $7.5 \mu \mathrm{l}$ of prothrombin (1.4 $\mu \mathrm{M})$ was then added. Reaction mixtures were incubated for $10 \mathrm{~min}$ and terminated by the addition of $0.5 \mathrm{ml}$ buffer $\mathrm{C}$, and $0.2-\mathrm{ml}$ aliquots were assayed for thrombin activity as described in Methods. Specific ${ }^{125} \mathrm{I}$-Factor $\mathrm{X}_{\mathbf{a}}$ binding was determined as described in Fig. 3. Thrombin concentration at $10 \mathrm{~min}$ is plotted against the amount of specifically bound ${ }^{125}$ I-Factor $X_{a}$. The mean of duplicate measurements is shown, and the experiment was repeated three times. be associated with perturbation of the endothelium, and infusion studies may provide further insight into the binding of Factor IX to the vessel wall in vivo. Factor VII, a coagulation factor reported not to bind specifically to bovine aortic endothelial cells in culture (46), was selected as a control for the vessel wall elution studies of Factor IX (Table I).

Factor $\mathrm{IX}_{\mathrm{a}}$ bound to vessel segments activated Factor $\mathrm{X}$ in the presence of exogenous VWF/Factor VIII and in the absence of exogenous phospholipid (Fig. 1, $A$ and $B$ ). In the experiments shown in Fig. 1, all of the specifically bound ${ }^{3} \mathrm{H}$-Factor $\mathrm{IX}_{\mathrm{a}}$ was considered to be active in Factor $\mathrm{X}$ cleavage. Specifically bound Factor $\mathrm{IX}_{\mathrm{a}}$ was responsible for the observed Factor $X$ activation since activation was prevented in the presence of a 100-fold molar excess of Factor IX, which prevents specific Factor $\mathrm{IX}_{\mathrm{a}}$ binding, or by elution of bound Factor $\mathrm{IX}_{\mathrm{a}}$ by calcium-free buffer. Further studies will be required to determine if all or only a portion of the specifically bound Factor $\mathrm{IX}_{\mathrm{a}}$ has procoagulant activity.

To study Factor $\mathrm{X}_{\mathrm{a}}$ generation, vessels were incubated with Factor IX and VWF/Factor VIII, and washed, and then catalytic amounts of thrombin were added and Factor $X$ activation was assessed. Since the vessel was essential for Factor $\mathrm{X}_{\mathrm{a}}$ formation, a complex of bound Factor $\mathrm{IX}_{\mathrm{a}}$ and activated VWF/Factor VIII may have formed on the vessel wall and functioned in a fashion analogous to the Factor $\mathrm{X}_{\mathrm{a}}-\mathrm{V}_{\mathrm{a}}$ complex in the activation of prothrombin (47-49). These results raise a number of questions concerning VWF/Factor VIII-vessel wall interactions.

Factor IX $\mathrm{X}_{\mathrm{a}}$ bound to aortic segments in the presence of adequate amounts of VWF/Factor VIII can initiate a series of vessel-dependent reactions leading to thrombin formation (Fig. $1 C$ ). Since the presumed activator of prothrombin was vesselbound Factor $\mathbf{X}_{\mathbf{a}}$ interaction with an endothelial cell Factor V-like molecule $(14,44)$, we next examined the interaction of Factor $X_{a}$ with vessel segments. When Factor $X_{a}$ was incubated with vessel segments, rapid inactivation occurred (Fig. 2). This is principally due to inactivation of the Factor $X_{a}$ by antithrombin III initially associated with the vessel. The details of this inactivation are uncertain (i.e., whether inactivation of 

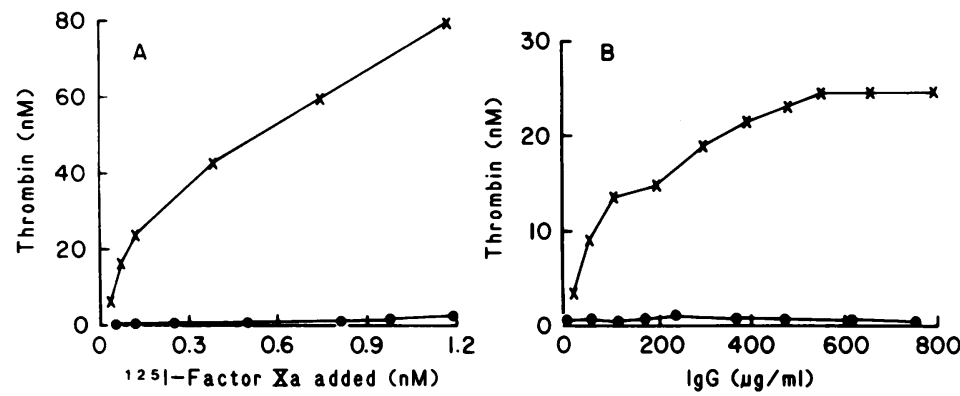

Figure 8. Effect of anti-antithrombin III IgG on the activation of prothrombin by Factor $\mathrm{X}_{\mathrm{a}}$ on aortic segments. $(A)$ Aortic wells were pre-incubated for $30 \mathrm{~min}$ with $600 \mu \mathrm{g} / \mathrm{ml}$ of either anti-antithrombin III IgG $(x)$ or control rabbit IgG (๑). ${ }^{125} \mathrm{I}$-Factor $\mathrm{X}_{\mathrm{a}}(0.05-1.2 \mathrm{nM})$ was then added to the wells for $5 \mathrm{~min}$, and the wells were washed. Buffer A (0.5 $\mathrm{ml})$, antibody, and prothrombin $(1.4 \mu \mathrm{M})$ were added. Reaction mixtures were incubated for $10 \mathrm{~min}$ and the supernatants were assayed for thrombin formation as described in Methods. $(B)$ Wells were incubated with varying amounts of either anti-antithrombin III IgG $(x)(2-800 \mu \mathrm{g} / \mathrm{ml})$ or control rabbit IgG $(\bullet)(2-800 \mu \mathrm{g} / \mathrm{ml})$ in $0.5 \mathrm{ml}$ buffer $A$ for 30

min. ${ }^{125} \mathrm{I}$-Factor $\mathrm{X}_{\mathrm{a}}(0.13 \mathrm{nM})$ was added to the wells and incubated for an additional $20 \mathrm{~min}$. Wells were then washed, and filled with fresh buffer $\mathrm{A}(0.5 \mathrm{ml})$, antibody (same as initially used for each well), and prothrombin $(1.4 \mu \mathrm{M})$. Reaction mixture supernatants were assayed for thrombin after $10 \mathrm{~min}$ of incubation. The mean of duplicate measurements is shown, and the experiment was repeated three times.

Factor $\mathrm{X}_{\mathrm{a}}$ results from Factor $\mathrm{X}_{\mathrm{a}}$ binding to antithrombin III localized on the vessel surface with subsequent dissociation of Factor $\mathrm{X}_{\mathrm{a}}$-antithrombin III complex or whether antithrombin III dissociates first and then Factor Xa-antithrombin III complex formation occurs in the supernatant), but the antithrombin III is clearly associated with the vessel at the start of the experiment (Table I). The mechanism responsible for this localization of antithrombin III to the vessel is currently under study. One possibility is that plasma antithrombin III binds to the vessel in vivo (50). Alternatively, constitutive synthesis of antithrombin III by endothelium, which has been reported for cultured human umbilical vein endothelial cells (51), may be involved.

Incubation of Factor $X_{a}$ with calf aortic segments showed the presence of time-dependent, specific binding (Fig. 3). The presence of antithrombin III decreased Factor $\mathrm{X}_{\mathrm{a}}$-vessel wall binding, whereas addition of anti-antithrombin III IgG, which blocked formation of ${ }^{125} \mathrm{I}$-Factor $\mathrm{X}_{\mathrm{a}}$-antithrombin III complex (Fig. 2, $B$ and $C$ ), promoted binding. This suggested that ${ }^{125} \mathrm{I}-$ Factor $\mathrm{X}_{\mathrm{a}}$, complexed with antithrombin III, no longer binds to the vessel segments. This suggestion was confirmed by experiments in which ${ }^{125} \mathrm{I}$-Factor $\mathrm{X}_{\mathrm{a}}$, pre-incubated with a twofold molar excess of antithrombin for $60 \mathrm{~min}$ at $37^{\circ} \mathrm{C}$, did not subsequently bind specifically to the vessels (unpublished observation). Also, SDS-PAGE of vessel-bound ${ }^{125} \mathrm{I}$-Factor $\mathrm{X}_{\mathrm{a}}$ did not reveal the presence of ${ }^{125} \mathrm{I}$-Factor $\mathrm{X}_{\mathrm{a}}$-antithrombin III complex (Fig. 5, $B$ and $C$ ). Binding of ${ }^{125} \mathrm{I}$-Factor $\mathrm{X}_{\mathrm{a}}$ to aortas in the presence of the plasma concentration of antithrombin III suggested that Factor $\mathrm{X}_{\mathrm{a}}$ binding to the vessel wall may occur physiologically. This observation led us to investigate further Factor $X_{\mathrm{a}}$-vessel wall interaction. Time-dependent binding of Factor $\mathrm{X}_{\mathrm{a}}$ to aortic segments (Fig. 4) was biphasic, with an initial rapid, largely reversible phase and a subsequent irreversible phase. Reversible binding was similar for ${ }^{125} I$-Factor $X_{\mathrm{a}}$ and ${ }^{125}$ I-Factor $X_{\mathrm{ai}}$ (Fig. 4), suggesting that integrity of the active site was not necessary for this vessel wall interaction. In contrast, the slower irreversible phase of binding required the active site and was due to formation of a covalent complex between Factor $X_{a}$ and a vessel-associated protein (Fig. 5). Factor $X_{a}$ bound to this site remained on the surface of the vessel since brief trypsin treatment $(2 \mathrm{mg} / \mathrm{ml}$ trypsin for
$4 \mathrm{~min}$ at $21^{\circ} \mathrm{C}$ ) did not remove the endothelium but did result in rapid dissociation of bound radioactivity. The nature of this ${ }^{125} \mathrm{I}$-Factor $\mathrm{X}_{\mathrm{a}}$ vessel wall complex is unclear, though it appears to differ in its molecular weight and antigenic characteristics from Factor $\mathrm{X}_{\mathrm{a}}$-antithrombin III complex. Competitive binding studies (Fig. 6) demonstrated no inhibition of ${ }^{125} I$-Factor $X_{a}$ binding by thrombin, suggesting that this was not the irreversible thrombin binding site observed by Lollar et al. (40) on cultured human umbilical vein endothelial cells. Further studies will be required to determine whether this binding site is an endogenous vessel wall nexin-like molecule (52) or an absorbed plasma protease inhibitor. Irreversible Factor $\mathrm{X}_{\mathrm{a}}$ binding due to covalent complex formation between Factor $\mathrm{X}_{\mathrm{a}}$ and an endothelial cell surface protein as well as binding of active site-blocked Factor $X_{a}$ were not seen by Rodgers and Shuman (14). These differences might be due to the variety of methods used to inactivate Factor $\mathrm{X}_{\mathrm{a}}$ or to different sources of endothelium, i.e., cultured vs. native endothelium.

Factor $\mathrm{X}_{\mathrm{a}}$ bound to aortic segments activated prothrombin (Fig. 7), though only small amounts of thrombin were detectable in the supernatant. Studies with anti-antithrombin III IgG (Fig. 8) suggested that most of the Factor $X_{a}$ added and thrombin formed were inactivated by antithrombin III initially associated with the surface of the vessel. Thus, in the presence of anti-antithrombin III IgG, which prevented antithrombin III protease complex formation, the amount of bound ${ }^{125} \mathrm{I}$-Factor $\mathrm{X}_{\mathrm{a}}$ (Fig. 3) and the amount of detectable thrombin in the amidolytic S2238 assay increased. The actual amount of thrombin formed per mole of Factor $\mathrm{X}_{\mathrm{a}}$ bound may have been unchanged. Under conditions of compromised blood flow in which exposure of the vessel wall to plasma antithrombin III might be reduced and/or antithrombin III associated with the vessel might dissociate, it is possible that more of the Factor $\mathrm{X}_{\mathrm{a}}$ and thrombin formed may remain active, potentially leading to fibrinogen cleavage and clot formation.

The presence of antithrombin III on the vessel surface is one mechanism by which the vessel wall is protected from activation of the coagulation system. Another potential protective mechanism is competition by Factors IX and IX for the same cellular binding site. When small amounts of Factor $\mathrm{IX}_{\mathrm{a}}$ 
are formed in the supernatant, no Factor $\mathrm{IX}_{\mathrm{a}}$ binding will occur as long as there is continuous blood flow to ensure a large excess of the zymogen, Factor IX. However, when the amount of Factor $\mathrm{IX}_{\mathrm{a}}$ in the supernatant increases, Factor IX binding could occur, as Factor IX already bound to the endothelium dissociates. (50\% of bound Factors IX/IX $\mathrm{X}_{\mathrm{a}}$ dissociates in $30 \mathrm{~min}$ at $4^{\circ} \mathrm{C}(9)$ and in $10 \mathrm{~min}$ at $23^{\circ} \mathrm{C}$.) Alternatively, activation of cell-bound Factor IX would lead to Factor $\mathrm{IX}_{\mathrm{a}}$ localized to the vessel wall. This cell-bound Factor $\mathrm{IX}_{\mathrm{a}}$ could then participate in Factor $\mathrm{X}$ activation since the dissociation of Factor $\mathrm{IX}_{\mathrm{a}}$ from its cellular binding site is slow. We have previously demonstrated activation of Factor IX bound to quiescent endothelial cells by Factor $\mathrm{XI}_{\mathrm{a}}$ and activation of Factor IX bound to endotoxin-treated endothelial cells, which express tissue factor, by Factor $\mathrm{VII}_{\mathrm{a}}(10)$. The cellbound Factor $\mathrm{IX}_{\mathrm{a}}$ formed did activate Factor $\mathrm{X}$ in the presence of VWF/Factor VIII. Therefore, an endothelial cell-dependent pathway of coagulation, initiated by perturbed endothelial cells expressing tissue factor and culminating in thrombin formation, may be an important mechanism for activation of the coagulation system in localized areas of vessel wall pathology. In these areas Factor $\mathrm{IX}_{\mathrm{a}}$ could be formed on the surface of endothelial cells, and Factor $X$ and prothrombin activation could proceed rapidly when the amount of antithrombin III on the vessel wall is decreased.

\section{Acknowledgments}

We gratefully acknowledge the excellent technical assistance of Jeff Harris and Melody Chase. The rapid production of many Lucite plates by Mr. Robert Stern and Mr. Milton Stern made these studies possible. We appreciate the helpful comments of Dr. S. Silverstein in the preparation of the manuscript.

This work was supported by grants from the National Institutes of Health (HL-15486, HL-21006, and HL-16919). Dr. Nawroth is supported by a grant from the Deutsche Forschungsgemeinschaft.

\section{References}

1. Weksler, B. B., A. J. Marcus, and E. A. Jaffe. 1977. Synthesis of protaglandin $\mathrm{I}_{2}$ (prostacyclin) by cultured human and bovine endothelial cells. Proc. Natl. Acad. Sci. USA. 74:3922-3926.

2. Loskutoff, D. J., and T. S. Edgington. 1977. Synthesis of a fibrinolytic activator and an inhibitor by endothelial cells. Proc. Natl. Acad. Sci. USA. 74:3903-3907.

3. Esmon, N. L., W. G. Owen, and C. T. Esmon. 1982. Isolation of a membrane-bound cofactor for thrombin-catalyzed activation of protein C. J. Biol. Chem. 257:859-864.

4. Busch, C., and W. G. Owen. 1982. Identification in vitro of an endothelial cell surface cofactor for antithrombin III. J. Clin. Invest. 69:726-729.

5. Lyberg, T., K. Galdal, S. Evensen, and H. Prydz. 1983. Cellular cooperation in endothelial cell thromboplastin synthesis. Br. J. Haematol. 53:85-95.

6. Jaffe, E. A., L. W. Hoyer, and R. L. Nachman. 1973. Synthesis of antihemophilic factor antigen by cultured human endothelial cells. J. Clin. Invest. 52:2757-2764.
7. Ingerman-Wojenski, C., M. J. Silver, J. B. Smith, and E. Macarak. 1981. Bovine aortic endothelial cells in culture produce thromboxane as well as prostacyclin. J. Clin. Invest. 67:1292-1296.

8. Stern, D., A. Hurlet-Jensen, and H. L. Nossel. 1982. Binding of human factor IX to endothelial cells. Fed. Proc. 41:1087. (Abstr.)

9. Stern, D. M., M. Drillings, H. L. Nossel, A. Hurlet-Jensen, K. LaGamma, and J. Owen. 1983. Binding of factors IX and IX to cultured vascular endothelial cells. Proc. Natl. Acad. Sci. USA. 80:41194123.

10. Stern, D. M., M. Drillings, W. Kisiel, P. Nawroth, H. L. Nossel, and K. S. LaGamma. 1983. Activation of factor IX bound to cultured bovine aortic endothelial cells. Proc. Natl. Acad. Sci. USA. 81:913917.

11. Heimark, R. L., and S. Schwartz. 1983. Binding of coagulation factors IX and $\mathrm{X}$ to the endothelial cell surface. Biochem. Biophys. Res. Commun. 111:723-731.

12. Stern, D., P. Nawroth, W. Kisiel, M. Drilings, J. Bartos, and H. Nossel. 1983. A pathway of coagulation from factor IX, to thrombin formation on the surface of endothelial cells. Blood. 62:310A. (Abstr.)

13. Rodgers, G. M., and M. A. Shuman. 1983. Characterization of a novel receptor for factor $\mathrm{X}_{\mathbf{a}}$ on bovine aortic endothelial cells. Blood. 62:308a. (Abstr.)

14. Rodgers, G. M., and M. A. Shuman. 1983. Prothrombin is activated on vascular endothelial cells by factor $\mathrm{X}_{\mathrm{a}}$ and calcium. Proc. Natl. Acad. Sci. USA. 80:7001-7005.

15. Fujikawa, K., A. R. Thompson, M. Legaz, R. Meyer, and E. Davie. 1973. Isolation and characterization of bovine factor IX. Biochemistry. 12:4938-4945.

16. David, G., and R. Reisfeld. 1974. Protein iodination with solid state lactoperoxidase. Biochemistry. 13:1014-1021.

17. Fujikawa, K., M. Legaz, and E. David. 1972. Bovine factors $X_{1}$ and $X_{2}$. Isolation and characterization. Biochemistry. 11:48824891.

18. Kisiel, W., H. Hermodson, and E. David. 1974. Factor X activating enzyme from Russell's Viper Venom. Isolation and characterization. Biochemistry. 15:4901-4906.

19. Fujikawa, J., M. Coan, M. Legaz, and E. Davie. 1974. The mechanism of activation of bovine factor $\mathrm{X}$ by intrinsic and extrinsic pathways. Biochemistry. 13:5290-5299.

20. Bajaj, P., and K. Mann. 1973. Simultaneous purification of bovine prothrombin and factor X. J. Biol. Chem. 248:7729-7741.

21. Laura, R., D. Robinson, and D. Bing. 1980. (p-Amidino phenyl)methanesulfonyl fluoride, an irreversible inhibitor of serine proteases. Biochemistry. 19:4859-4864.

22. Furie, B. C., B. Furie, A. J. Gottlieb, and W. Williams. 1974. Activation of bovine factor $\mathrm{X}$ by the venom coagulant protein of Vipera Russeli: complex formation of the activation fragments. Biochimica Biophys. Acta. 365:121-132.

23. Newman, J., A. Johnson, M. Karpatkin, and S. Paszkin. 1971. Methods for the production of clinically effective intermediate and high purity factor VIII concentrates. Br. J. Haematol. 21:1-20.

24. Van Dieijan, G., G. Tans, J. Rosing, and H. C. Hemker. 1981. The role of phospholipid and factor VIII $_{\mathrm{a}}$ in the activation of bovine factor X. J. Biol. Chem. 256:3433-3442.

25. Lundblad, R. L., L. C. Uhteg, C. N. Vogel, H. S. Kingdon, and K. G. Mann. 1975. Preparation and partial characterization of two forms of bovine thrombin. Biochem. Biophys. Res. Commun. 66:482-486.

26. Mann, K. G. 1976. Prothrombin. Methods Enzymol. 45:123156. 
27. Kisiel, W., and E. Davie. 1975. Isolation and characterization of bovine factor III. Biochemistry. 14:4928-4934.

28. Fraker, P., and J. Speck. 1978. Protein and cell membrane iodinations with a sparingly soluble chloramine 1,3,4,6-tetrachloro3a,6a-diphenylglycoluril. Biochem. Biophys. Res. Commun. 80:849857.

29. Broze, G. 1982. Binding of human Factors VII and VII, to monocytes. J. Clin. Invest. 70:526-535.

30. Mahoney, W. C., K. Kurachi, and M. A. Hermodson. 1980. Formation and dissociation of the covalent complexes between trypsin and two homologous inhibitors, $\alpha_{1}$-antitrypsin and antithrombin III. Eur. J. Biochem. 105:545-552.

31. Harboe, N., and A. Ingild. 1973. Immunization, isolation of immunoglobulins, and estimation of antibody titre. In A Manual of Quantitative Immunoelectrophoresis. N. H. Axelson, J. Kroll, and B. Weeke, editors. Universitetsforlaget, Oslo. 161-164.

32. Tracy, P., J. Petersen, M. Nesheim, F. McDuffie, and K. G. Mann. 1979. Interaction of coagulation factor $\mathrm{V}$ and factor $\mathrm{V}_{\mathrm{a}}$ with platelets. J. Biol. Chem. 254:10354-10361.

33. Lowry, O., N. Rosebrough, L. Farr, and R. Randall. 1951. Protein measurement with Folin reagent. J. Biol. Chem. 193:265-275.

34. Chase, T., and E. Shaw. 1969. Comparison of the esterase activities of trypsin, plasmin, and thrombin on guanidinobenzoate esters. Titration of enzymes. Biochemistry. 8:2212-2224.

35. Stern, D., H. Nossel, and J. Owen. 1982. Acquired antibody to Factor XI in a patient with congenital Factor XI deficiency. J. Clin. Invest. 69:1270-1276.

36. Detwiler, T., and R. Feinman. 1973. Kinetics of thrombininduced release of calcium (II) by platelets. Biochemistry. 12:282-288.

37. Kurachi, K., K. Fujikawa, G. Schmer, and E. W. Davie. 1976. Inhibition of bovine factor IX, and factor $\mathrm{X}_{\mathbf{a} \beta}$ by antithrombin III. Biochemistry. 15:373-377.

38. Rosenberg, R., and P. Damus. 1973. The purification and mechanism of action of human antithrombin-heparin cofactor. J. Biol. Chem. 248:6490-6505.

39. Hayat, A. M. 1972. Principles and Techniques of Electron Microscopy. Van Nostrand Reinhold Co., Inc., New York. 1-252.

40. Lollar, P., J. C. Hoak, and W. G. Owen. 1980. Binding of thrombin to cultured human endothelial cells. J. Biol. Chem. 255:1027910283.
41. Rosing, J., G. Tans, J. W. P. Govers-Riemslag, R. F. A. Zwaal, and H. C. Hemker. 1980. The role of phospholipids and factor $V_{a}$ in the prothrombinase complex. J. Biol. Chem. 255:274-283.

42. Odegard, O., A. Abildgaard, M. Lie, and M. Miller-Andersson. 1977. Inactivation of bovine and human thrombin and factor $X_{\mathbf{a}}$ by antithrombin III studied with amidolytic methods. Thromb. Res. 11:205-216.

43. Suzuki, L. A., and A. R. Thompson. 1982. Factor IX antigen by a rapid Staphylococcal protein A-membrane binding radioimmunoassay; results in haemophilia B patients and carriers in fetal samples. Br. J. Haematol. 50:673-682.

44. Cerveny, T., D. Fass, and K. G. Mann. 1983. Coagulation factor V synthesis by cultured endothelium. Fed. Proc. 42:1032. (Abstr.)

45. Fuchs, H. E., and S. V. Pizzo. 1983. Regulation of factor $X_{a}$ in vitro in human and mouse plasma and in vivo in mouse: role of the endothelium and plasma proteinase inhibitors. J. Clin. Invest. 72:2041-2049.

46. Rodgers, G., G. Borze, and M. Shuman. 1984. The number of receptors for factor VII correlates with the ability of cultured cells to initiate coagulation. Blood. 63:434-438.

47. Miletich, J., C. Jackson, and P. Majerus. 1977. Interaction of coagulation factor $\mathrm{X}_{\mathrm{a}}$ with human platelets. Proc. Natl. Acad. Sci. USA. 74:4033-4036.

48. Tracy, P. B., M. E. Nesheim, and K. G. Mann. 1981. Coordinate binding of factor $V_{a}$ and factor $X_{a}$ to the unstimulated platelet. J. Biol. Chem. 256:743-751.

49. Dahlback, B., and J. Stenflo. 1978. Binding of bovine coagulation factor $\mathrm{X}_{\mathrm{a}}$ to platelets. Biochem. J. 23:4938-4945.

50. Stern, D., P. Nawroth, W. Kisiel, D. Handley, M. Drillings, and J. Bartos. 1984. Activity and binding of antithrombin III on bovine aortic segments. Clin. Res. 32:499A. (Abstr.)

51. Chan, V., and T. Chan. 1979. Antithrombin III in fresh and cultured human endothelial cells: a natural anticoagulant from the vascular endothelium. Thromb. Res. 15:209-213.

52. Baker, J. B., D. A. Low, R. L. Simmer, and D. D. Cunningham. 1980. Protease-nexin: a cellular component that links thrombin and plasminogen activator and mediates their binding to cells. Cell. 21:37-45. 